\title{
The Impact of the COVID-19 Pandemic on Consumers' Preferences for Wood Furniture: An Accounting Perspective
}

\author{
Jianxiong Chen and Chung-Cheng Yang * \\ Department of Accounting, National Yunlin University of Science and Technology, Yunlin 64002, Taiwan; \\ D10825001@yuntech.edu.tw \\ * Correspondence: ycc19660619@gmail.com
}

Citation: Chen, J.; Yang, C.-C. The Impact of the COVID-19 Pandemic on Consumers' Preferences for Wood Furniture: An Accounting Perspective. Forests 2021, 12, 1637. https://doi.org/10.3390/f12121637

Academic Editor: Davide M. Pettenella

Received: 4 November 2021 Accepted: 20 November 2021 Published: 25 November 2021

Publisher's Note: MDPI stays neutral with regard to jurisdictional claims in published maps and institutional affiliations.

Copyright: (c) 2021 by the authors. Licensee MDPI, Basel, Switzerland. This article is an open access article distributed under the terms and conditions of the Creative Commons Attribution (CC BY) license (https:// creativecommons.org/licenses/by/ $4.0 /)$.

\begin{abstract}
The COVID-19 pandemic has had a major impact on forest product markets and the forest product industry, and has also seriously affected the sales of forest products. This research aimed to analyze people's preference for wood furniture and make policy recommendations. We examined the impact of the pandemic on consumers' preferences for wood furniture from the perspective of accounting. Taking the accounting data of wood furniture enterprises as the research object, through the translog revenue function, and using the relationship between revenue and consumption in economics, we found that the COVID-19 pandemic has reduced consumers' preferences for wood furniture, but the decline in preference is smaller for wood furniture produced by extra-large furniture manufacturers. This study contributes to the literature and in view of our research results and the severity of the COVID-19 pandemic, we provide policy suggestions for the related governmental agencies and wood furniture manufacturers, in this special environment, that can reduce the negative impact of a pandemic on the wood furniture industry.
\end{abstract}

Keywords: COVID-19; consumers' preferences; accounting perspective; wood furniture sales

\section{Introduction}

The COVID-19 pandemic has had a huge impact on the economy, the environment, and most human activities [1], and an economic downturn is evident in almost every country [2]. GDP growth has slowed [3], people's jobs have become less stable, incomes have generally fallen, consumption preferences have become uncertain, and many different countries have adopted lockdown measures or extreme social distancing measures to control the spread of COVID-19 [4]. The pandemic has also had a significant impact on the sales of forest products, which play an important role in people's lives, such as wood products, forest chemical products, and wood crafts, which are widely used by people. The purpose of this study was to analyze the impact of the pandemic on consumers' preferences for wood furniture from an accounting perspective.

The furniture industry is one representative industry of China's light industries, and it is also a representative industry of China's export economy. Since the 1990s, China's economy has risen steadily. At present, China is the world's largest furniture producer [5], exporter, and consumer [6], and occupies an important position in the global furniture export trade. Wood furniture is the largest field in China's furniture industry. With the development of China's furniture industry, the market scale of wood furniture is also expanding, and its proportion in the furniture industry tends to increase year by year. Most of the revenue of the Chinese furniture industry is determined by the sales of wood furniture. At present, wood furniture occupies a critical position in the Chinese furniture industry and strongly represents the Chinese furniture industry [7]. Chinese wood furniture is favored by many domestic and international consumers and has a broad appeal. Wood furniture is also an essential part of the wood industry chain, which can promote sustainable development of the wood industry [8]. 
In recent decades, China's forestry and timber industry has accelerated development. This progress has made China the most significant participant in the global wooden raw material market, and the largest exporter of value-added wooden products [9]. After entering the 21st century, the Chinese government proposed accelerating the pace of urbanization to stimulate the consumer market. This move of the Chinese government has further promoted China's housing construction and the development of housing-related industries, such as the furniture industry. According to the needs of society and development, the State Council of China proposed the industrialization of housing. This move has promoted the standardization of tens of thousands of housing-supporting products. Due to the development of housing industrialization, housing has entered the market as a commodity, providing development space for all kinds of wood furniture and supporting products. China's wood furniture industry has enormous market potential. Chinese consumers have a stronger consumer preference for wood furniture presently, especially with the acceleration of China's urbanization process after 2010, which has further increased the consumer preference for wood furniture in the Chinese market [10]. China's achievements in lifting hundreds of millions of people out of poverty has brought the lives of the Chinese people into a new stage of development, and the demand for wood furniture and consumer preferences for it have also been further improved.

Although forest resources are limited, domestic production and forest product processing industries have developed rapidly with the strengthening of national economic growth. Since 2004, China has been a significant exporter of wood furniture, surpassing traditional European exporters [9]. Chinese furniture is mainly exported to the United States, Germany, Britain, France, and Canada, among which the United States is the largest export destination for Chinese furniture products. Since joining the WTO, China's furniture exports have almost always maintained a growth trend. After a brief decline during the 2008 financial crisis, furniture exports have resumed their growth and maintained continuous growth for six years. Affected by many unfavorable factors, such as rising labor, raw materials, logistics, and environmental protection costs, China's furniture export value fell sharply in 2016, and recovered slowly in 2017. In 2018, the export value increased by $7.6 \%$ year-on-year, and in 2019 , it continued to increase by $0.8 \%$ year-on-year, reaching $\$ 54.1$ billion.

Starting in 2020, the COVID-19 pandemic not only lowered the expectations of global economic growth, but also negatively impacted the international market demand for China's furniture exports. After the outbreak of the COVID-19 pandemic, consumer markets in Europe and the United States gradually shrank, and consumption expectations dropped significantly; foreign trade companies were generally faced with the suspension or cancellation of orders by international buyers, especially in the furniture industry, which witnessed a sharp drop in export volume caused by demand-side factors, economic recession and reduced consumer demand caused by the severe COVID-19 pandemic in major destination countries, and the closure of downstream furniture enterprises. This resulted in China's furniture industry having export difficulties.

In addition to the difficulties faced by furniture exporters, in China's domestic market, the government has taken various measures to deal with the COVID-19 pandemic, which also has had a significant impact on consumers' consumption preferences for wood furniture. As COVID-19 spreads globally, a common public policy response is to force the temporary closure of non-essential business activities [11]. Studies have shown that restricting interpersonal contact or restricting traffic is effective in curbing the spread of the virus [12,13], but these restrictions prevent consumers from going to malls to buy furniture. Although studies have shown that these interventions reduce the negative economic consequences of the pandemic [14-16], some scholars have warned about the cost-effectiveness of social distancing [17] and demonstrated the direct and indirect economic costs of such interventions [18]. While the specific impact of the new coronavirus's transmission mode [19,20], the spread rate [21], morbidity, and mortality [22] on the economy and consumer behavior is still controversial, the serious economic uncertainty caused by the COVID-19 pandemic 
and increased inconvenience for consumers to go to furniture stores, and its impact on the international furniture market, we expect that the COVID-19 pandemic will reduce consumer spending on wood furniture; that is, the COVID-19 pandemic has already reduced consumers' preferences for wood furniture.

In this study, the impact of the COVID-19 pandemic on the consumption preferences of consumers for wood furniture was investigated by constructing the furniture industry translog revenue function for empirical analysis. Our findings have made some contributions. First, to our knowledge, we are the first to use furniture industry revenue functions in consumer preference studies to explore the substantial impact of a major public health emergency. Second, according to our research, the negative impact of the COVID-19 pandemic on wood furniture consumption preferences can be mitigated through effective marketing. In response to the export risks of international orders caused by the COVID-19 pandemic and the furniture export dilemma caused by traffic restrictions, we have proposed specific measures for furniture companies to consider. In view of the reduction of consumers' preferences for wood furniture caused by the COVID-19 pandemic, we have put forward suggestions for consideration by governmental and regulatory authorities. Third, China is the world's largest exporter of wood furniture, and changes in international consumers' preferences for Chinese wood furniture have a direct impact on the furniture market in many countries. Our study may provide valuable references for the formulation of furniture trade policies and the adjustment of export furniture structures in other countries (especially those countries with significant furniture trade market competition with China).

This study aimed to determine the specific impact of COVID-19 on consumers' preference for wood furniture from an accounting perspective and propose policy recommendations. The rest of this article is organized as follows: in the second section, we will introduce the institutional background, and discuss our main hypotheses. The third section describes the study design and data source. The fourth section gives the empirical results, and the final section discusses the impact of the findings of this study on consumers' preferences for wood furniture.

\section{Background and Hypothesis Development}

Studies by many scholars have found that widespread infectious diseases have serious negative effects on society and the economy. A global pandemic would significantly reduce per capita income and deal a negative blow to the global forest product markets and to the forest product industry. Moreover, changes in income will further have a significant impact on consumer preferences. Many scholars have studied the impact that the COVID-19 pandemic has had on the economy and society, conducting extensive and in-depth studies on the pandemic.

Since the outbreak of the COVID-19 pandemic, researchers and policymakers have been interested in research on the impact of the COVID-19 pandemic on industries, and many studies have analyzed industry data. These include studies of the tourist industry [23-29], hotel industry [24,28,30-32], energy industry [33-35], cruise industry [27,36,37], aviation industry [38-40], restaurant industry [32,41], food industry [42-45], poultry industry [46-48], IT services industry [49], electricity industry [50,51], tobacco industry [52], insurance industry $[53,54]$, construction industry $[55,56]$, and forestry and wood industry $[57,58]$. The above-mentioned research mainly focuses on the negative impact of the pandemic on public consumption behavior, society, or related industries. The COVID-19 pandemic has had a significant impact on people's consumer behavior and industrial conditions in developed markets. The above are the reasons we have a strong interest in studying the impact of the COVID-19 pandemic on consumer preferences related to the furniture industry in China, an emerging market.

In the face of severe cases of illness caused by the pandemic, people's insecurity when going out has risen to an extremely high level, and government departments have also required people to stay at home as much as possible, and have closed many entertainment 
facilities and stores. Traffic restrictions and social communication obstructions have caused people to have different degrees of psychological pressure [59-62], and due to the sharp decline in time spent outside the home, people have been forced to reduce their purchases of daily necessities in physical stores. The pandemic has severely disrupted the economic market. In China, furniture stores led by Red Star Macalline and Easyhome announced the delay of opening immediately after the start of the pandemic. The performance of the leaders of the two furniture stores dropped sharply as a result, which in turn had an impact on furniture manufacturers. In terms of online sales, during the pandemic, large furniture stores, including Red Star Macalline and Easyhome, began selling online, one after another, using their own or public live broadcast platforms to open online marketing and home delivery of goods.

The overall social consumption expenditures have shown a significant downward trend under the pandemic, and people's consumption of forest products has also dropped significantly. Due to the impact of COVID-19, China's macroeconomic growth slowed down in 2020, and China's GDP growth suffered a negative effect. COVID-19 has primarily hurt residents' disposable income, reduced residents' consumption expectations, and thus affected furniture consumption. As consumers have lower purchasing power during the pandemic and wood furniture is not their priority (compared to medicine or food), we expect that COVID-19 will further reduce consumers' preferences for wood furniture.

In China's furniture market, the COVID-19 pandemic has not only reduced consumers' enthusiasm for going to furniture stores, but also led to a serious decline in sales in the real estate market, which has greatly inhibited the demand for furniture. As one of the main markets of the furniture industry, real estate has had a great impact on the sales of wood furniture. The COVID-19 pandemic has caused a huge shock to the economy, which has reduced the sales of real estate, and further affected consumers' preferences for wood furniture. Some home furniture, especially the kind used in a home office, is at high demand due the mode of working from home. However, COVID-19 has also had a profound impact on the sales of home office furniture. On the one hand, the recurring outbreaks of the COVID-19 pandemic in China has led to intermittent closures of furniture stores in some cities, which reduces the chance of consumers' contact with wood furniture. On the other hand, during the pandemic, people are generally afraid of being infected [59,60], and the frequency of going out and spending by many people has been drastically reduced. Office furniture is non-essential under the pandemic, and there are many alternatives. In such times, people can use daily furniture to replace home office furniture. Moreover, consumers have naturally reduced the frequency of going to furniture stores to purchase home office furniture, which has led to a sharp decrease in the exposure of consumers to wood furniture in the market. Obviously, the pandemic has had a negative impact on consumers' preferences for wood furniture.

From the perspective of the main destination countries of Chinese furniture, the United States is the most important destination country, followed by Britain, Japan, Germany, and Australia. The major destination countries of Chinese furniture have been facing high numbers of severe cases, according to statistics from the Center for Systems Science and Engineering at Johns Hopkins University. As of 31 December 2020, and the United States had a cumulative total of 20,100,244 confirmed cases and a cumulative total of 351,980 deaths. The United States is the country with the largest cumulative number of confirmed cases and deaths in the world. The UK had a total of 2,496,235 confirmed cases and a total of 73,622 deaths by that time. The total number of confirmed cases and deaths in the UK ranks seventh among the countries in the world; Germany had a total of 1,760,520 confirmed cases and a total of 33,791 deaths. The total number of confirmed cases in Germany ranked 11th among countries in the world at that time. Japan has a total of 235,811 confirmed cases and a total of 3292 deaths. A total of 28,425 cases have been confirmed in Australia. The COVID-19 pandemic continues to spread in the above countries, which put China's furniture exports under greater export pressure in 2020. 
Affected by the rapid spread of the COVID-19 pandemic, governments have continuously upgraded control measures. According to the regulatory requirements of many governments, in the retail industry, physical stores other than stores selling necessities, such as food and medicine, were often closed on a large scale. The government's control measures have caused psychological pressure on people $[60,61,63]$ and made the furniture industry face severe challenges. The closure of home furnishing retail stores resulted in the stagnation of the sales of furniture products, and the operating conditions of furniture retail enterprises in destination countries were greatly impacted by government controls, which increased the risks to Chinese furniture exporters.

In view of the significant adverse impact of the COVID-19 pandemic on the domestic and international furniture market, we expect that the COVID-19 pandemic has reduced consumers' preferences for wood furniture. In addition, the frequency of people going to furniture stores has been greatly reduced, and the sales of wood furniture of nonextra-large furniture manufacturers have been negatively affected to a larger extent due to poor online sales application experience. The research results of Liu et al. [64] show that the credibility of enterprises has a significant impact on consumer preferences, and high-credibility information sources are more likely to increase consumers' preferences for relevant products. Different from non-extra-large furniture manufacturers, extra-large furniture manufacturers have more efficient online sales platforms. Therefore, we expect that under the COVID-19 pandemic, the reduction of consumers' preferences will be smaller for wood furniture of extra-large furniture enterprises. We list the hypothesis below:

Hypothesis 1 (H1). The COVID-19 pandemic has reduced consumers' preferences for wood furniture, but the decline in preference will be smaller for wood furniture produced by extra-large furniture manufacturers.

\section{Method}

\subsection{Theoretical Model}

The sales of enterprises can effectively reflect consumption trends and preference for products. This study uses the revenue of the furniture enterprise to estimate the consumption trend of wood furniture, and further estimates the consumption preferences of the population from consumption trends.

The human capital of different positions plays a vital role in developing enterprises, and the cooperation between human capital will promote the production efficiency of enterprises [65-67]. The production function of furniture company is as follows:

$$
y=f\left(x_{1}, x_{2}, x_{3}, a, d\right)
$$

where $y$ is the sales of the furniture company, $x_{1}$ is the number of management posts in the furniture company, $x_{2}$ is the number of R\&D posts in the furniture company, $x_{3}$ is the number of ordinary positions in the furniture company, $a$ is the investment in fixed assets, and $d$ is the R\&D investment of furniture enterprises. In the above equation, the investment needs of enterprises are $\geq 0: y \geq 0, x_{i} \geq 0, a \geq 0, d \geq 0$, and $i=1,2,3$. At the same time, all the above variables must meet these basic theoretical requirements: $\partial f(\cdot) / \partial x_{i} \geq 0, \partial f(\cdot) / \partial a \geq 0, \partial f(\cdot) / \partial d \geq 0, \partial^{2} f(\cdot) / \partial x_{i}^{2} \leq 0, \partial^{2} f(\cdot) / \partial a^{2} \leq 0$, and $\partial^{2} f(\cdot) / \partial d^{2} \leq 0$.

Based on the above, the revenue function of the furniture industry can be expressed by this equation:

$$
r\left(p ; x_{1}, x_{2}, x_{3}, a, d\right)=\text { max pysubjecttoy }=f\left(x_{1}, x_{2}, x_{3}, a, d\right)
$$

In the above equation, $r$ and $p$ are the revenue and the price of furniture, respectively. The two variables are the most critical in the revenue function. We express this equation as follows:

$$
\ln r=\alpha_{0}+\delta \ln p+\sum_{i=1}^{3} \alpha_{i} \ln x_{i}+\beta_{1} \ln a+\delta_{1} \ln d
$$


This model is a revenue function generated based on Cobb-Douglas. Its characteristic is that the price homogeneity is equal to $1(\delta=1)$, and it needs to be normalized with $p=1[68]$ as follows:

$$
\ln r=\alpha_{0}+\sum_{i=1}^{3} \alpha_{i} \ln x_{i}+\beta_{1} \ln a+\delta_{1} \ln d
$$

As a reference a series of studies on the revenue function model by previous scholars [69], and this research specifies the revenue function of the furniture companies as follows:

$$
\begin{aligned}
\ln r=\alpha_{0} & +\sum_{i=1}^{3} \alpha_{i} \ln x_{i}+\beta_{1} \ln a+\delta_{1} \ln d+\frac{1}{2} \sum_{i=1}^{3} \sum_{l=1}^{3} \alpha_{i l} \ln x_{i} \ln x_{l}+\frac{1}{2} \beta_{11}(\ln a)^{2} \\
& +\frac{1}{2} \delta_{11}(\ln d)^{2}+\sum_{i=1}^{3} \gamma_{i 1} \ln x_{i} \ln a+\sum_{i=1}^{3} \varepsilon_{i 1} \ln x_{i} \ln d+\theta_{11} \ln a \ln d .
\end{aligned}
$$

In the model, if $\alpha_{i l}=\beta_{11}=\delta_{11}=\gamma_{i 1}=\varepsilon_{i 1}=\theta_{11}=0$, according to economic theory, this equation regress to a Cobb-Douglas.

\subsection{Data and Variables}

\subsubsection{Data Source and Sample Period}

The China Stock Market and Accounting Research database contains financial accounting report information, and many scholars use this database to obtain data for quantitative research [70-74]. Through the China Stock Market and Accounting Research database, this research has obtained a lot of accounting data, for example, the revenue and fixed assets of the Chinese furniture enterprises in each quarter from 2015-2020. There are 436 observations for listed companies in the Chinese furniture industry from 2015 to 2020. Considering original data with errors or null values, we deleted some unreasonable data, such as the revenue is 0 , fixed assets are 0 , and research and development expenses are 0 . After deducting unreasonable observations, there were remaining valid observations 391.

We define extra-large furniture companies in terms of quarterly revenue. Among the 391 effective observations, the proportions of extra-large furniture companies and non-extra-large furniture companies are $18.41 \%$ and $81.59 \%$, respectively. Taking 2020 as an example, the revenue of China's extra-large furniture companies accounted for 39.00\% of the entire furniture industry's revenue. Extra-large furniture companies have a very large market share and are recognized by consumers.

\subsubsection{Variable Definitions}

First, since our research model is closely related to the revenue of the furniture industry, we need to define the total revenue (REVENUE). Second, staff positions in furniture companies usually include management positions (MANAGER), R\&D positions $(R D)$, and ordinary positions (ORDINARY). In addition, fixed assets (FASSET) and research and development expenditures (DEVE) is particularly important in the investment of the furniture industry, so we add these two critical variables to the model.

We added COVID-19 (COVID). In 2020, COVID is 1 ; in 2015-2020, COVID is 0. Through COVID, we can accurately judge the impact of the pandemic on wood furniture consumption preferences. In China, the furniture products of the three extra-large furniture companies (BIG) with the largest quarterly revenue are very popular and have a very high market share. Even in a pandemic, consumers' preference for the furniture products of three major furniture companies with the largest quarterly revenue are quite different from that of other companies. When BIG is 1 , it represents the three extra-large furniture companies with the largest quarterly revenue; when $B I G$ is 0 , it means the nonthree extra-large furniture companies. We also added $B I G^{*} C O V I D$ as an interactive item. Through the interactive item, we can judge the impact of the pandemic on consumer preferences for furniture companies of different sizes. Variable definitions are shown in Table 1. 
Table 1. Variable definitions.

\begin{tabular}{ccl}
\hline \multicolumn{2}{c}{ Variable } & \multicolumn{1}{c}{ Definition } \\
\cline { 1 - 2 } Theoretical Variable & Proxy Variable & \\
\cline { 1 - 2 }$x_{1}$ & REVENUE & The revenue of furniture enterprises \\
$x_{2}$ & MANAGER & Total number of management positions \\
$x_{3}$ & RD & Total number of research positions \\
& ORDINARY & Total number of ordinary positions \\
$d$ & EMPLOYEE & Total number of positions \\
& FASSET & Net fixed assets of company \\
& DEVE & R\&D investment \\
& BIG & When BIG is 1, it represents the three extra-large furniture companies; \\
& COVID & COVID represents the beginning of COVID-19. In 2020, COVID is 1; in \\
\end{tabular}

\subsection{Estimation Model}

The usual research methods in economics need to be transformed from theoretical models to estimation models required in empirical research. Next, we combine various variables of the furniture industry with the translog revenue function. These variables include the revenue of all the furniture companies (REVENUE), various human resources, FASSET, DEVE, COVID and BIG. Based on the above, we can also analyze whether the population has different consumption preferences for wood furniture produced by extralarge and non-extra-large enterprises. The following is the estimation model:

$$
\begin{aligned}
& \ln R E V E N U E=\alpha_{0}+\alpha_{1} \ln M A N A G E R+\alpha_{2} \ln R D+\alpha_{3} \ln \text { ORDINARY }+\beta_{1} \ln F A S S E T+\delta_{1} \ln D E V E \\
& +\frac{1}{2} \alpha_{11}(\ln M A N A G E R)^{2}+\frac{1}{2} \alpha_{22}(\ln R D)^{2}+\frac{1}{2} \alpha_{33}(\ln O R D I N A R Y)^{2}+\frac{1}{2} \beta_{11}(\ln F A S S E T)^{2} \\
& +\frac{1}{2} \delta_{11}(\ln D E V E)^{2}+\alpha_{12} \ln M A N A G E R \ln R D+\alpha_{13} \ln M A N A G E R \ln O R D I N A R Y \\
& +\alpha_{23} \ln R D \ln O R D I N A R Y+\gamma_{11} \ln M A N A G E R \ln F A S S E T+\gamma_{21} \ln R D \ln F A S S E T \\
& +\gamma_{31} \ln \text { ORDINARYlnFASSET }+\varepsilon_{11} \ln M A N A G E R \ln D E V E+\varepsilon_{21} \ln R D \ln D E V E \\
& +\varepsilon_{31} \ln \text { ORDINARYlnDEVE }+\theta_{11} \ln F A S S E T \ln D E V E+\varphi_{1} B I G+\varphi_{2} \text { COVID } \\
& +\varphi_{3} \text { BIG COVID }
\end{aligned}
$$

Based on the above model and the data we obtained from the database, this study can estimate the average partial effect (APE) of critical variables on REVENUE of furniture enterprises:

The APE of MANAGER, RD, ORDINARY, FASSET, DEVE, BIG and COVID on REVENUE:

$\partial \ln \widehat{R E V E N U E / \partial \ln M A N A G E R}$

$$
\begin{aligned}
& =\hat{\alpha}_{1}+\hat{\alpha}_{11} \overline{\ln M A N A G E R}+\hat{\alpha}_{12} \overline{\ln R D}+\hat{\alpha}_{13} \overline{\ln \text { ORDINARY }} \\
& +\hat{\gamma}_{11} \overline{\ln F A S S E T}+\hat{\varepsilon}_{11} \overline{\ln D E V E}
\end{aligned}
$$

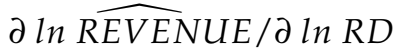

$$
\begin{aligned}
& =\hat{\alpha}_{2}+\hat{\alpha}_{22} \overline{\ln R D}+\hat{\alpha}_{12} \overline{\ln M A N A G E R}+\hat{\alpha}_{23} \overline{\ln \text { ORDINARY }} \\
& +\hat{\gamma}_{21} \overline{\ln F A S S E T}+\hat{\varepsilon}_{21} \overline{\ln D E V E}
\end{aligned}
$$

$\partial \ln \widehat{R E V E N U E / \partial} \ln$ ORDINARY

$$
\begin{aligned}
& =\hat{\alpha}_{3}+\hat{\alpha}_{33} \overline{\ln \text { ORDINARY }}+\hat{\alpha}_{13} \overline{\ln M A N A G E R}+\hat{\alpha}_{23} \overline{\ln R D} \\
& +\hat{\gamma}_{31} \overline{\ln F A S S E T}+\hat{\varepsilon}_{31} \overline{\ln D E V E}
\end{aligned}
$$

$\partial \ln \widehat{R E V E N U E / \partial \ln F A S S E T}$

$$
\begin{aligned}
& =\hat{\beta}_{1}+\hat{\beta}_{11} \overline{\ln F A S S E T}+\hat{\gamma}_{11} \overline{\ln M A N A G E R}+\hat{\gamma}_{21} \overline{\ln R D} \\
& +\hat{\gamma}_{31} \overline{\ln \text { ORDINARY }}+\hat{\gamma}_{11} \overline{\ln D E V E}
\end{aligned}
$$


$\partial \ln \widehat{R E V E N U E / \partial \ln D E V E}$

$$
\begin{aligned}
& =\hat{\delta}_{1}+\hat{\delta}_{11} \overline{\ln D E V E}+\hat{\varepsilon}_{11} \overline{\ln M A N A G E R}+\hat{\varepsilon}_{21} \overline{\ln R D} \\
& +\hat{\varepsilon}_{31} \overline{\ln \text { ORDINARY }}+\hat{\theta}_{11} \overline{\ln \text { FASSET }} \\
& \partial \ln \widehat{R E V E N U E} / \partial \ln B I G=\varphi_{1}+\varphi_{3} \text { COVID } \\
& \partial \ln \widehat{R E V E N U E} / \partial \operatorname{COVID}=\varphi_{2}+\varphi_{3} \text { BIG }
\end{aligned}
$$

\section{Results}

\subsection{Descriptive Statistics and Correlation Matrix}

From Table 2, we can see that in the past six years, the revenue of the furniture industry

\begin{tabular}{|c|c|c|c|c|c|c|c|c|c|c|c|c|}
\hline \multirow{3}{*}{$\begin{array}{c}\text { Panel A: } \\
\text { Variables } \\
\text { REVENUE }\end{array}$} & \multicolumn{6}{|c|}{$2015(n=30)$} & \multicolumn{6}{|c|}{$2016(n=38)$} \\
\hline & Mean & Median & Max & Min & Std. Dev. & Kurtosis & Mean & Median & Max & Min & Std. Dev. & Kurtosis \\
\hline & $¥ 1020.00$ & $¥ 795.00$ & $¥ 3540.00$ & $¥ 82.60$ & $¥ 869.00$ & 4.44 & $¥ 1370.00$ & $¥ 1050.00$ & $¥ 4790.00$ & $¥ 108.00$ & $¥ 1190.00$ & 4.31 \\
\hline$M A N A G E R$ & 13.07 & 13.50 & 16.00 & 10.00 & 2.18 & 1.65 & 13.50 & 14.00 & 18.00 & 8.00 & 2.69 & 2.82 \\
\hline$R D$ & 271.83 & 250.00 & 694.00 & 32.00 & 246.08 & $\begin{array}{l}1.00 \\
1.96\end{array}$ & 344.97 & 231.00 & 1123.00 & 81.00 & 316.96 & 4.28 \\
\hline ORDINARY & 4059.43 & 3098.00 & $10,126.00$ & 677.00 & 2900.50 & 3.06 & 4123.47 & 2649.00 & $10,589.00$ & 771.00 & 3157.64 & 2.57 \\
\hline EMPLOYEE & 4344.33 & 3358.00 & $10,835.00$ & 782.00 & 3112.26 & 3.03 & 4481.95 & 2864.00 & $11,271.00$ & 887.00 & 3398.41 & 2.42 \\
\hline FASSET & $¥ 500.00$ & $¥ 403.00$ & $¥ 1050.00$ & $¥ 37.70$ & $¥ 317.00$ & 2.00 & $¥ 564.00$ & $¥ 444.00$ & $¥ 1170.00$ & $¥ 47.25$ & $¥ 371.00$ & 1.59 \\
\hline DEVE & $¥ 33.03$ & $¥ 38.45$ & $¥ 64.64$ & $¥ 4.54$ & $¥ 18.23$ & 2.30 & $¥ 52.75$ & $¥ 46.67$ & $¥ 96.10$ & $¥ 18.35$ & $¥ 23.34$ & $\begin{array}{l}1.39 \\
2.46\end{array}$ \\
\hline Panel B: & \multicolumn{6}{|c|}{$2017(n=68)$} & \multicolumn{6}{|c|}{$2018(n=82)$} \\
\hline Variables & Mean & Median & Max & Min & Std. Dev. & Kurtosis & Mean & Median & Max & Min & Std. Dev. & Kurtosis \\
\hline REVENUE & $¥ 1740.00$ & $¥ 960.00$ & $¥ 9710.00$ & $¥ 90.44$ & $¥ 1900.00$ & 7.27 & $¥ 1900.00$ & $¥ 1100.00$ & $¥ 11,500.00$ & $¥ 76.62$ & $¥ 2190.00$ & 8.23 \\
\hline MANAGER & 13.82 & 14.00 & 19.00 & 8.00 & 2.80 & 2.81 & 14.10 & 14.00 & 19.00 & 8.00 & 2.84 & 2.52 \\
\hline$R D$ & 486.00 & 294.00 & 1993.00 & 91.00 & 517.84 & 5.12 & 510.22 & 397.00 & 2533.00 & 68.00 & 544.53 & 9.87 \\
\hline ORDINARY & 5403.31 & 2775.00 & $16,125.00$ & 634.00 & 5070.83 & 2.65 & 5330.15 & 3289.00 & $17,170.00$ & 687.00 & 4848.27 & 3.08 \\
\hline EMPLOYEE & 5903.13 & 2940.00 & $18,129.00$ & 804.00 & 5532.57 & 2.81 & 5854.46 & 3589.00 & $19,714.00$ & 906.00 & 5315.22 & 3.48 \\
\hline FASSET & $¥ 643.00$ & $¥ 435.00$ & $¥ 2490.00$ & $¥ 62.43$ & $¥ 551.00$ & 4.16 & $¥ 786.00$ & $¥ 514.00$ & $¥ 3460.00$ & $¥ 67.82$ & $¥ 759.00$ & 6.32 \\
\hline DEVE & $¥ 82.63$ & $¥ 66.16$ & $¥ 320.00$ & $¥ 14.16$ & $¥ 76.39$ & 6.13 & $¥ 110.00$ & $¥ 82.24$ & $¥ 632.00$ & $¥ 18.40$ & $¥ 129.00$ & 13.39 \\
\hline Panel C: & \multicolumn{6}{|c|}{$2019(n=85)$} & \multicolumn{6}{|c|}{$2020(n=88)$} \\
\hline Variables & Mean & Median & Max & Min & Std. Dev. & Kurtosis & Mean & Median & Max & Min & Std. Dev. & Kurtosis \\
\hline REVENUE & $¥ 2100.00$ & $¥ 1150.00$ & $¥ 13,500.00$ & $¥ 72.16$ & $¥ 2520.00$. & 9.03 & $¥ 2260.00$ & $¥ 1220.00$ & $¥ 14,700.00$ & $¥ 35.66$ & $¥ 2710.00$ & 9.36 \\
\hline MANAGER & 13.73 & 14.00 & 19.00 & 9.00 & 2.86 & 2.14 & 13.77 & 15.00 & 19.00 & 9.00 & 2.69 & 2.06 \\
\hline$R D$ & 602.79 & 419.00 & 2866.00 & 64.00 & 652.67 & 7.80 & 619.95 & 478.50 & 2774.00 & 57.00 & 605.84 & 7.82 \\
\hline ORDINARY & 5381.64 & 3293.00 & $18,785.00$ & 528.00 & $\begin{array}{l}002.07 \\
4916.09\end{array}$ & 3.69 & 5905.14 & 4206.50 & $17,239.00$ & 499.00 & $\begin{array}{l}003.04 \\
4937.93\end{array}$ & 2.77 \\
\hline EMPLOYEE & 5998.15 & 3558.00 & $21,660.00$ & 723.00 & 5524.27 & 4.08 & 6538.86 & 4827.00 & $20,022.00$ & 592.00 & 5472.13 & 3.05 \\
\hline FASSET & $¥ 927.00$ & $¥ 629.00$ & $¥ 4960.00$ & $¥ 164.00$ & $¥ 921.00$ & $\begin{array}{l}4.00 \\
8.15\end{array}$ & $¥ 1130.00$ & $¥ 780.00$ & $¥ 6090.00$ & $¥ 180.00$ & $¥ 1140.00$ & 8.97 \\
\hline DEVE & $¥ 122.00$ & $¥ 90.78$ & $¥ 642.00$ & $¥ 13.08$ & $¥ 132.00$ & 11.80 & $¥ 138.00$ & $¥ 113.00$ & $¥ 699.00$ & $¥ 10.05$ & $¥ 141.00$ & 11.71 \\
\hline
\end{tabular}
has shown an increasing trend, and the industry has developed relatively well. In 2019, the average revenue of the furniture industry reached $¥ 2100$ million.

Table 2. Descriptive statistics.

Note: All variables' definitions are the same as Table 1.

However, we pay attention to the potential crisis in the furniture industry. From the perspective of the revenue trends from 2015 to 2020, the average revenue growth rate of the furniture industry has been declining almost year by year. In the past five years, the revenue growth rate was $34.31 \%, 27.01 \%, 9.20 \%, 10.53 \%$, and $7.62 \%$. The impact of the COVID-19 pandemic on the furniture industry has reduced consumers' willingness to purchase furniture to a certain extent.

In addition, from 2015 to 2020, the average number of R\&D personnel increased from 272 in 2015 to 620 in 2020, an increase of $128.07 \%$ in six years, and the average number of R\&D personnel more than doubled in the past six years. The average R\&D investment of furniture companies increased almost year by year in the past six years, from 33.03 million in 2015 to 138.00 million in 2020, an increase of $242.11 \%$, and the growth is greater than the personnel input. It is rare to see such a large-scale increase in R\&D investment in a short period in other industries. This also shows that furniture companies generally believe that by actively researching and developing new types of furniture, consumers can increase preferences for their furniture products.

Table 3 shows the correlation coefficients. COVID and REVENUE are positively correlated, but the correlation is drawn without controlling for other variables. After we control other variables, we can analyze the impact of COVID on REVENUE through APE, and we will have a more accurate conclusion. COVID is positively correlated with $R D$ and DEVE. After the COVID-19 pandemic, to increase consumers' willingness to purchase furniture, enterprises increased their investment in $R \& D$ to maximize sales. 
Table 3. Correlation matrix.

\begin{tabular}{|c|c|c|c|c|c|c|c|c|c|}
\hline & (1) & (2) & (3) & (4) & (5) & (6) & (7) & (8) & (9) \\
\hline (1) REVENUE & 1.000 & $\begin{array}{c}0.269 \\
(0.000)\end{array}$ & $\begin{array}{c}0.632 \\
(0.000)\end{array}$ & $\begin{array}{c}0.723 \\
(0.000)\end{array}$ & $\begin{array}{c}0.724 \\
(0.000)\end{array}$ & $\begin{array}{c}0.718 \\
(0.000)\end{array}$ & $\begin{array}{c}0.698 \\
(0.000)\end{array}$ & $\begin{array}{c}0.466 \\
(0.000)\end{array}$ & $\begin{array}{c}0.057 \\
(0.259)\end{array}$ \\
\hline (2) MANAGER & $\begin{array}{c}0.098 \\
(0.052)\end{array}$ & 1.000 & $\begin{array}{c}0.198 \\
(0.000)\end{array}$ & $\begin{array}{c}0.249 \\
(0.000)\end{array}$ & $\begin{array}{c}0.247 \\
(0.000)\end{array}$ & $\begin{array}{c}0.277 \\
(0.000)\end{array}$ & $\begin{array}{c}0.270 \\
(0.000)\end{array}$ & $\begin{array}{l}-0.059 \\
(0.242)\end{array}$ & $\begin{array}{c}0.031 \\
(0.542)\end{array}$ \\
\hline (3) RD & $\begin{array}{c}0.656 \\
(0.000)\end{array}$ & $\begin{array}{c}0.021 \\
(0.685)\end{array}$ & $\begin{array}{c}1.000 \\
----\end{array}$ & $\begin{array}{c}0.801 \\
(0.000)\end{array}$ & $\begin{array}{c}0.832 \\
(0.000)\end{array}$ & $\begin{array}{c}0.651 \\
(0.000)\end{array}$ & $\begin{array}{c}0.879 \\
(0.000)\end{array}$ & $\begin{array}{c}0.493 \\
(0.000)\end{array}$ & $\begin{array}{c}0.123 \\
(0.015)\end{array}$ \\
\hline (4) ORDINARY & $\begin{array}{c}0.722 \\
(0.000) \\
\end{array}$ & $\begin{array}{c}0.175 \\
(0.000) \\
\end{array}$ & $\begin{array}{c}0.868 \\
(0.000)\end{array}$ & 1.000 & $\begin{array}{c}0.997 \\
(0.000)\end{array}$ & $\begin{array}{c}0.805 \\
(0.000)\end{array}$ & $\begin{array}{c}0.825 \\
(0.000)\end{array}$ & $\begin{array}{c}0.556 \\
(0.000)\end{array}$ & $\begin{array}{c}0.064 \\
(0.205)\end{array}$ \\
\hline (5) EMPLOYEE & $\begin{array}{c}0.724 \\
(0.000)\end{array}$ & $\begin{array}{c}0.162 \\
(0.001)\end{array}$ & $\begin{array}{c}0.893 \\
(0.000)\end{array}$ & $\begin{array}{c}0.999 \\
(0.000)\end{array}$ & $\begin{array}{l}1.000 \\
----\end{array}$ & $\begin{array}{c}0.802 \\
(0.000)\end{array}$ & $\begin{array}{c}0.844 \\
(0.000)\end{array}$ & $\begin{array}{c}0.556 \\
(0.000)\end{array}$ & $\begin{array}{c}0.081 \\
(0.109)\end{array}$ \\
\hline (6) FASSET & $\begin{array}{c}0.738 \\
(0.000)\end{array}$ & $\begin{array}{l}-0.011 \\
(0.825)\end{array}$ & $\begin{array}{c}0.786 \\
(0.000)\end{array}$ & $\begin{array}{c}0.759 \\
(0.000)\end{array}$ & $\begin{array}{c}0.771 \\
(0.000)\end{array}$ & $\begin{array}{l}1.000 \\
----\end{array}$ & $\begin{array}{c}0.731 \\
(0.000)\end{array}$ & $\begin{array}{c}0.529 \\
(0.000)\end{array}$ & $\begin{array}{c}0.175 \\
(0.001)\end{array}$ \\
\hline (7) DEVE & $\begin{array}{c}0.654 \\
(0.000)\end{array}$ & $\begin{array}{c}-0.046 \\
(0.368)\end{array}$ & $\begin{array}{c}0.937 \\
(0.000)\end{array}$ & $\begin{array}{c}0.789 \\
(0.000)\end{array}$ & $\begin{array}{c}0.814 \\
(0.000)\end{array}$ & $\begin{array}{c}0.845 \\
(0.000)\end{array}$ & 1.000 & $\begin{array}{c}0.367 \\
(0.000)\end{array}$ & $\begin{array}{c}0.221 \\
(0.000)\end{array}$ \\
\hline (8) BIG & $\begin{array}{c}0.548 \\
(0.000)\end{array}$ & $\begin{array}{l}-0.079 \\
(0.120)\end{array}$ & $\begin{array}{c}0.544 \\
(0.000)\end{array}$ & $\begin{array}{c}0.636 \\
(0.000)\end{array}$ & $\begin{array}{c}0.634 \\
(0.000)\end{array}$ & $\begin{array}{c}0.585 \\
(0.000)\end{array}$ & $\begin{array}{c}0.479 \\
(0.000)\end{array}$ & 1.000 & $\begin{array}{c}-0.066 \\
(0.190)\end{array}$ \\
\hline (9) COVID & $\begin{array}{c}0.093 \\
(0.066)\end{array}$ & $\begin{array}{c}0.003 \\
(0.959)\end{array}$ & $\begin{array}{c}0.101 \\
(0.046)\end{array}$ & $\begin{array}{c}0.073 \\
(0.147)\end{array}$ & $\begin{array}{c}0.077 \\
(0.127)\end{array}$ & $\begin{array}{c}0.196 \\
(0.000)\end{array}$ & $\begin{array}{c}0.161 \\
(0.001)\end{array}$ & $\begin{array}{c}-0.066 \\
(0.190)\end{array}$ & $\begin{array}{l}1.000 \\
----\end{array}$ \\
\hline
\end{tabular}

Note: The upper triangle is the Spearman correlation coefficient, the lower triangle is the Pearson correlation coefficient.

\subsection{The Pandemic and Wood Furniture Consumption Preferences}

COVID-19 started to develop on a large scale in 2020. Therefore, we used 2020 as the breakpoint, the F statistic is 3.29. This result significantly rejects the null hypothesis. The results of this empirical model show that the pandemic has affected consumers' preferences. Next, COVID and BIG were added as essential variables to this research model to analyze the impact of COVID-19 on consumers' preferences for wood furniture. We need to emphasize that the purpose of adding the dummy variable BIG is to estimate the impact of COVID-19 on the wood furniture consumption preferences of furniture companies of different sizes.

\subsection{Estimation Results}

\subsubsection{The Revenue Function}

This research uses the translog model to estimate more accurate empirical results. Scholars generally believe that the translog model is more suitable for industry research than the Cobb-Douglas model. Still, to establish that the translog model is more suitable for this study, we need to analyze it according to the specific situation of the industry. Through the following equation, we can verify the adaptability of the model in the furniture industry:

$$
\alpha_{i l}=\beta_{11}=\delta_{11}=\gamma_{i 1}=\varepsilon_{i 1}=\theta_{11}=0 \text { for all } i=1,2,3 .
$$

From Table 4, we can see that the F statistic is 1.58. This proves that the translog model can better analyze consumers' preferences for wood furniture in the environment of the pandemic.

\subsubsection{Consumption Preferences for Wood Furniture}

We list the average partial effect (APE) of all variables in this study in Table 5. The APE of COVID to the total revenue is negative. Table 4 shows that COVID is negative in the translog revenue model. The relevant results in Tables 4 and 5 show that the pandemic has reduced consumers' preferences for wood furniture. 
Table 4. Translog estimates.

\begin{tabular}{|c|c|c|c|}
\hline \multirow{2}{*}{ Variable } & Coefficient & \multirow{2}{*}{ Variable } & \multirow{2}{*}{$\begin{array}{c}\text { Coefficient } \\
t \text {-Value }\end{array}$} \\
\hline & $t$-Value & & \\
\hline Intercept & $\begin{array}{l}-15.273 \\
(-0.339)\end{array}$ & $(\ln O R D I N A R Y)(\ln M A N A G E R)$ & $\begin{array}{c}0.084 \\
(0.111)\end{array}$ \\
\hline $\ln M A N A G E R$ & $\begin{array}{l}17.076 \\
(1.563)\end{array}$ & $(\ln O R D I N A R Y)(\ln R D)$ & $\begin{array}{c}0.213 \\
(0.810)\end{array}$ \\
\hline $\ln R D$ & $\begin{array}{l}-1.183 \\
(-0.263)\end{array}$ & $(\ln M A N A G E R)(\ln F A S S E T)$ & $\begin{array}{c}0.421 \\
(0.823)\end{array}$ \\
\hline $\operatorname{lnORDINARY}$ & $\begin{array}{l}-1.696 \\
(-0.408)\end{array}$ & $(\ln R D)(\ln F A S S E T)$ & $\begin{array}{c}0.162 \\
(0.648)\end{array}$ \\
\hline $\ln F A S S E T$ & $\begin{array}{c}2.095 \\
(0.590)\end{array}$ & $(\operatorname{lnORDINARY)(\operatorname {ln}FASSET)}$ & $\begin{array}{c}0.238 \\
(1.311)\end{array}$ \\
\hline $\ln D E V E$ & $\begin{array}{l}-0.879 \\
(-0.173)\end{array}$ & $(\ln M A N A G E R)(\ln D E V E)$ & $\begin{array}{c}-1.935^{* * *} \\
(-2.595)\end{array}$ \\
\hline$(\ln M A N A G E R)^{2}$ & $\begin{array}{c}0.019 \\
(0.020)\end{array}$ & $(\ln R D)(\ln D E V E)$ & $\begin{array}{l}-0.412 \\
(-1.281)\end{array}$ \\
\hline$(\ln R D)^{2}$ & $\begin{array}{c}-0.081 \\
(-0.501)\end{array}$ & $(\ln O R D I N A R Y)(\ln D E V E)$ & $\begin{array}{c}-0.265 \\
(-1.501)\end{array}$ \\
\hline$(\ln O R D I N A R Y)^{2}$ & $\begin{array}{c}0.033 \\
(0.287)\end{array}$ & $(\ln F A S S E T)(\ln D E V E)$ & $\begin{array}{l}-0.101 \\
(-0.420)\end{array}$ \\
\hline$(\ln F A S S E T)^{2}$ & $\begin{array}{l}-0.095 \\
(-0.884)\end{array}$ & $B I G$ & $\begin{array}{c}0.090 \\
(0.544)\end{array}$ \\
\hline$(\ln D E V E)^{2}$ & $\begin{array}{l}0.365 * \\
(1.674)\end{array}$ & COVID & $\begin{array}{l}-0.255^{* *} \\
(-2.353)\end{array}$ \\
\hline$(\ln M A N A G E R)(\ln R D)$ & $\begin{array}{l}1.575^{*} \\
(1.858)\end{array}$ & BIGCOVID & $\begin{array}{c}0.235 \\
(0.908)\end{array}$ \\
\hline $\begin{array}{c}\text { Adjusted R-squared } \\
\text { System degrees of freedom }\end{array}$ & & $\begin{array}{c}0.601 \\
391\end{array}$ & \\
\hline $\begin{array}{c}\text { F-statistic } \\
\text { Significance level }\end{array}$ & linear specifict & $\begin{array}{c}\left.11=\delta_{11}=\gamma_{i 1}=\varepsilon_{i 1}=\theta_{11}=0\right) \\
1.58 \\
0.000\end{array}$ & \\
\hline
\end{tabular}

Note: All variables' definitions are the same as Tables 1 and $2 .{ }^{*}, * *, * * *$ Denote significance at the $0.10,0.05$, and 0.01 levels, respectively (two-tailed for all $t$-statistics).

The possible reason is that furniture stores are still the most important channel for wood furniture sales. Unlike many other products, furniture usually requires consumers to have on-site experience to increase their understanding and preference of the furniture. Moreover, since the COVID-19 pandemic caused the government to take measures to restrict traffic and reduced outdoor activities, which caused a great inconvenience for consumers to go to stores to buy furniture, consumers' experiences with furniture were reduced, and this even made it difficult for some consumers to have actual experiences shopping for furniture.

In addition, we found from Table 5 that the APE of COVID to extra-large furniture is -0.020 , which is greater than the APE of COVID to non-extra-large furniture $(-0.255)$, indicating that the COVID-19 pandemic has a smaller impact on the purchase preference of wood furniture on BIG. This is because BIG has a convenient online sales platform, $B I G^{\prime}$ s furniture shopping mobile application and website have a better furniture purchase experiences (e.g., immersive 3D furniture displays, a large number of positive comments on online sales, etc.). Compared with non-BIG, BIG has increased consumers' preferences for furniture through online sales platforms. However, it should be noted that BIG's total furniture sales are still negatively affected by COVID-19. This verifies the hypothesis of this study. 
Table 5. APE of variables on REVENUE.

\begin{tabular}{ccc}
\hline APE & Value Estimated Value & Significance Test \\
\hline APE_ORDINARY & & $H_{0}: \alpha_{3}=\alpha_{33}=\alpha_{13}=\alpha_{23}=\gamma_{31}=\varepsilon_{31}=0$ \\
$F$-statistic $=2.14$ \\
Significance level $=0.05$
\end{tabular}

\section{Conclusions and Discussion}

Many scholars have conducted related research on the impact of COVID-19 on consumers. Zhang et al. [75] compared the results of topic classification and sentiment analysis before and after the epidemic and found that the psychological attitudes of catering consumers during the COVID-19 pandemic were more positive. Jin et al. [76] conducted two online surveys on China's Credamo data platform and found that the pandemic has had a positive impact on scarce consumption behavior. There is a big difference between this study and the research conclusions of the aforementioned scholars. We analyze from the perspective of accounting data, and the research results show that the COVID-19 pandemic has reduced consumers' preferences for wood furniture, but the decline in preference is smaller for wood furniture produced by extra-large furniture manufacturers.

The sustainable development of the industry is closely related to economic efficiency [77-79]. We believe that the sustainable development of the wood furniture industry can be promoted through corporate marketing channels to improve the negative impact of the COVID-19 pandemic on wood furniture consumption preferences. One step would be for enterprises to make consumers more aware of wood furniture by opening online furniture exhibitions. A second step would be for enterprises to increase consumers' on-site wood furniture experience by opening offline furniture exhibitions. Regarding international wood furniture orders, we suggest that furniture export enterprises comprehensively evaluate the orders in hand, pay attention to the decline in consumer preferences for wood furniture caused by the COVID-19 pandemic, and negotiate with buyers in time for orders that may be suspended or cancelled by customers, so as to reduce export risks. We also call on the government to give more consideration to increasing people's willingness to consume by issuing vouchers and cash, which will also benefit the wood furniture industry.

Policymakers can consider the following measures: (1) more furniture stores should be allowed to resume opening, which can allow more consumers to enter the furniture stores, better understand wood furniture, and increase consumers' preference for wood furniture; (2) helping furniture companies improve online sales channels. Through online sales channels, the furniture produced by non-extra-large furniture companies can obtain more attention, which can also effectively increase consumers' understanding and preference of wood furniture; and (3) the government can consider providing convenient channels for 
furniture exports. The overseas market is an important market for China's wood furniture sales. Restoring the convenience of furniture exports will help wood furniture increase its exposure in overseas consumer markets and increase overseas consumers' preference for wood furniture.

We studied the impact of the COVID-19 pandemic on the consumption preferences for wood furniture produced by Chinese manufacturers from the timeline of furniture industry data spanning 6 years, but our research lacks a horizontal comparison between different economies. Different economies have different economic conditions and coronavirus infection situations, especially as the gap between developing countries and developed countries is even wider. We suggest that if future research can obtain detailed data of the sales situation of wood furniture in highly developed capital markets (e.g., the United States) before and after the outbreak of the COVID-19 pandemic, and compare it horizontally with our research results, we expect that this research will provide a complete picture of the impact of the COVID-19 pandemic on the consumption preferences for wood furniture in different types of markets around the world.

Author Contributions: J.C. proposed the idea, collected data, established the model, completed the empirical tests, finished the original and final draft of this paper. C.-C.Y. analyzed the results and gave significant suggestions to the implications of the results. All authors have read and agreed to the published version of the manuscript.

Funding: This research received no external funding.

Institutional Review Board Statement: Not applicable.

Informed Consent Statement: Not applicable.

Data Availability Statement: All relevant data are within the manuscript.

Conflicts of Interest: The authors declare no conflict of interest.

\section{References}

1. Siche, R. What is the impact of COVID-19 disease on agriculture? Sci. Agropecu. 2020, 11, 3-6. [CrossRef]

2. Hitka, M.; Štarchoň, P.; Caha, Z.; Lorincová, S.; Sedliačiková, M. The global health pandemic and its impact on the motivation of employees in micro and small enterprises: A case study in the Slovak Republic. Econ. Res.-Ekon. Istraživanja. $2021,1-21$. [CrossRef]

3. Zhang, J. Five basic insights into the economic impact of the COVID-19 outbreak. Front. Econ. China 2020, 15, 167-178.

4. Codagnone, C.; Bogliacino, F.; Gómez, C.; Charris, R.; Montealegre, F.; Liva, G.; Veltri, G.A. Assessing concerns for the economic consequence of the COVID-19 response and mental health problems associated with economic vulnerability and negative economic shock in Italy, Spain, and the United Kingdom. PLoS ONE 2020, 15, e0240876. [CrossRef]

5. Xu, X.; Wang, S.; Yu, Y. Consumer's Intention to Purchase Green Furniture: Do Health Consciousness and Environmental Awareness Matter? Sci. Total Environ. 2020, 704, 135275. [CrossRef]

6. Yan, S. Research on the Spatial Characteristics and the Sustainable Development Strategies of Chinese Furniture Industry. Curr. Urban Stud. 2017, 5, 403. [CrossRef]

7. Prospective Industry Research Institute. Analysis of the Status Quo of China's Wood Furniture Industry in 2018. Available online: https:/ / www.qianzhan.com/analyst/detail/220/180521-7a609872.html (accessed on 9 November 2021). (In Chinese)

8. Xiong, X.Q.; Guo, W.J.; Fang, L.; Zhang, M.; Wu, Z.H.; Lu, R.; Miyakoshi, T. Current State and Development Trend of Chinese Furniture Industry. J. Wood Sci. 2017, 63, 433-444. [CrossRef]

9. Barbu, M.C.; Tudor, E.M. State of the art of the Chinese forestry, wood industry and its markets. Wood Mater. Sci. Eng. 2021, 1-10. [CrossRef]

10. Lu, H.L.; Li, J.H.; Li, G.Y.; Hu, J.N.; Wang, M.T. Research on the Impact of Natural Forest Protection Project on China's Forest Product Trade. Iss. For. Econ. 2020, 6, 634-642. (In Chinese)

11. Cowling, M.; Brown, R.; Rocha, A. Did you save some cash for a rainy COVID-19 day? The crisis and SMEs. Int. Small Bus. J. 2020, 38, 593-604. [CrossRef]

12. Greenstone, M.; Nigam, V. Does Social Distancing Matter; Working Paper 202026; University of Chicago: Chicago, IL, USA, 2020.

13. Fang, H.; Wang, L.; Yang, Y. Human Mobility Restrictions and the Spread of the Novel Coronavirus (2019-ncov) in china. J. Public Econ. 2020, 191, 104272. [CrossRef]

14. Correia, S.; Luck, S.; Verner, E. Pandemics Depress the Economy, Public Health Interventions Do Not: Evidence From the 1918 Flu. SSRN Electron. J. 2020, 1-56. [CrossRef]

15. Duan, H.; Wang, S.; Yang, C. Coronavirus: Limit Short-Term Economic Damage. Nature 2020, 578, 515-516. [CrossRef] 
16. Li, K.; Qin, Y.; Wu, J.; Yan, J. Containing the Virus or Reviving the Economy? Evidence from Individual Expectations during the COVID-19 Epidemic. SSRN Electron. J. 2020. [CrossRef]

17. Adda, J. Economic Activity and the Spread of Viral Diseases: Evidence from High Frequency Data. Q. J. Econ. 2016, 131, 891-941. [CrossRef]

18. Eichenbaum, M.S.; Rebelo, S.; Trabandt, M. The Macroeconomics of Epidemics; Working Paper 26882; Northwestern University: Evanston, IL, USA, 2020.

19. Ferretti, L.; Wymant, C.; Kendall, M.; Zhao, L.; Nurtay, A.; Abeler-Dörner, L.; Parker, M.; Bonsall, D.; Fraser, C. Quantifying SARS-CoV-2 Transmission Suggests Epidemic Control with Digital Contact Tracing. Science 2020, 368, eabb6936. [CrossRef]

20. Wong, J.E.; Leo, Y.S.; Tan, C.C. COVID-19 in Singapore-Current Experience: Critical Global Issues that Require Attention and Action. Jama 2020, 323, 1243-1244. [CrossRef]

21. Li, Q.; Guan, X.; Wu, P.; Wang, X.; Zhou, L.; Tong, Y.; Feng, Z. Early Transmission Dynamics in Wuhan, China, of Novel Coronavirus-Infected Pneumonia. N. Engl. J. Med. 2020, 382, 1199-1207. [CrossRef]

22. Tian, H.; Liu, Y.; Li, Y.; Wu, C.H.; Chen, B.; Kraemer, M.U.; Dye, C. An Investigation of Transmission Control Measures during the First 50 Days of the COVID-19 Epidemic in China. Science 2020, 368, 638-642. [CrossRef]

23. Arbulú, I.; Razumova, M.; Rey-Maquieira, J.; Sastre, F. Can Domestic Tourism Relieve the COVID-19 Tourist Industry Crisis? The Case of Spain. J. Destin. Mark. Manag. 2021, 20, 100568. [CrossRef]

24. Kaushal, V.; Srivastava, S. Hospitality and Tourism Industry Amid COVID-19 Pandemic: Perspectives on Challenges and Learnings from India. Int. J. Hosp. Manag. 2021, 92, 102707. [CrossRef]

25. Škare, M.; Soriano, D.R.; Porada-Rochoń, M. Impact of COVID-19 on the Travel and Tourism Industry. Technol. Forecast. Soc. 2021, 163, 120469. [CrossRef]

26. Rogerson, C.M.; Rogerson, J.M. COVID-19 Tourism Impacts in South Africa: Government and Industry Responses. Geoj. Tour. 2020, 31, 1083-1091. [CrossRef]

27. Renaud, L. Reconsidering Global Mobility-Distancing from Mass Cruise Tourism in the Aftermath of COVID-19. Tour. Geogr. 2020, 22, 679-689. [CrossRef]

28. Karim, W.; Haque, A.; Anis, Z.; Ulfy, M.A. The Movement Control Order (MCO) for COVID-19 Crisis and Its Impact on Tourism and Hospitality Sector in Malaysia. Int. Tour. Hosp. J. 2020, 3, 1-7. [CrossRef]

29. Miller-Rushing, A.J.; Athearn, N.; Blackford, T.; Brigham, C.; Cohen, L.; Cole-Will, R.; Super, P.E. COVID-19 pandemic impacts on conservation research, management, and public engagement in US national parks. Biol. Conserv. 2021, 257, 109038. [CrossRef]

30. Anguera-Torrell, O.; Aznar-Alarcón, J.P.; Vives-Perez, J. COVID-19: Hotel Industry Response to the Pandemic Evolution and to the Public Sector Economic Measures. Tour. Recreat. Res. 2020, 46, 148-157. [CrossRef]

31. Davahli, M.R.; Karwowski, W.; Sonmez, S.; Apostolopoulos, Y. The Hospitality Industry in the Face of the COVID-19 Pandemic: Current Topics and Research Methods. Int. J. Environ. Res. Public Health 2020, 17, 7366. [CrossRef]

32. Dube, K.; Nhamo, G.; Chikodzi, D. COVID-19 Cripples Global Restaurant and Hospitality Industry. Curr. Issues Tour. 2021, 24, 1487-1490. [CrossRef]

33. Fu, M.; Shen, H. COVID-19 and Corporate Performance in the Energy Industry. Energy Res. Lett. 2020, 1, 12967. [CrossRef]

34. Polemis, M.; Soursou, S. Assessing the Impact of the COVID-19 Pandemic on the Greek Energy Firms: An Event Study Analysis. Energy Res. Lett. 2020, 1, 17238. [CrossRef]

35. Jiang, P.; Van Fan, Y.; Klemeš, J.J. Impacts of COVID-19 on Energy Demand and Consumption: Challenges, Lessons and Emerging Opportunities. Appl. Energy 2021, 285, 116441. [CrossRef] [PubMed]

36. Ito, H.; Hanaoka, S.; Kawasaki, T. The Cruise Industry and the COVID-19 Outbreak. Transp. Res. Interdiscip. Perspect. 2020, 5, 100136. [CrossRef] [PubMed]

37. Ilhan, E.G.E. The Impact of Coronavirus Disease (COVID-19) Pandemic on Cruise Industry: Case of Diamond Princess Cruise Ship. Mersin. Univ. J. Marit. Fac. 2020, 2, 32-37.

38. Dube, K.; Nhamo, G.; Chikodzi, D. COVID-19 Pandemic and Prospects for Recovery of the Global Aviation Industry. J. Air Transp. Manag. 2021, 92, 102022. [CrossRef]

39. Rahman, N.A.A.; Rahim, S.A.; Ahmad, M.F.; Hafizuddin-Syah, B.A.M. Exploring COVID-19 Pandemic: Its Impact to Global Aviation Industry and the Key Strategy. Int. J. Adv. Sci. Technol. 2020, 26, 1829-1836.

40. Salman, D.; Seiam, D.; Fayaz, E. How Can the Aviation Sector Survive after COVID-19? Virtual Econ. 2020, 3, 91-105. [CrossRef]

41. Song, H.J.; Yeon, J.; Lee, S. Impact of the COVID-19 Pandemic: Evidence from the U.S. Restaurant Industry. Int. J. Hosp. Manag. 2021, 92, 102702. [CrossRef]

42. Chowdhury, M.T.; Sarkar, A.; Paul, S.K.; Moktadir, M.A. A Case Study on Strategies to Deal with the Impacts of COVID-19 Pandemic in the Food and Beverage Industry. Oper. Manag. Res. 2020, 1-13. [CrossRef]

43. Zuber, S.; Brüssow, H. COVID 19: Challenges for Virologists in the Food Industry. Microb. Biotechnol. 2020, $13,1689-1701$. [CrossRef]

44. Ziliak, J.P. Food Hardship during the COVID-19 Pandemic and Great Recession. Appl. Econ. Perspect. Policy 2021, 43, 132-152. [CrossRef]

45. Chenarides, L.; Manfredo, M.; Richards, T.J. COVID-19 and Food Supply Chains. Appl. Econ. Perspect. Policy 2021, 43, 270-279. [CrossRef] 
46. Hafez, H.M.; Attia, Y.A. Challenges to the Poultry Industry: Current Perspectives and Strategic Future after the COVID-19 Outbreak. Front. Vet. Sci. 2020, 7, 516. [CrossRef]

47. Yazdekhasti, A.; Wang, J.; Zhang, L.; Ma, J. A Multi-Period Multi-Modal Stochastic Supply Chain Model under COVID Pandemic: A Poultry Industry Case Study in Mississippi. Transp. Res. Part E Logist. Transp. Rev. 2021, 154, 102463. [CrossRef]

48. Biswal, J.; Vijayalakshmy, K.; Rahman, H. Impact of COVID-19 and Associated Lockdown on Livestock and Poultry Sectors in India. Vet. World 2020, 13, 1928. [CrossRef]

49. Shankar, K. The Impact of COVID-19 on IT Services Industry-Expected Transformations. Br. J. Manag. 2020, 31, 450. [CrossRef]

50. Zhong, H.; Tan, Z.; He, Y.; Xie, L.; Kang, C. Implications of COVID-19 for the Electricity Industry: A Comprehensive Review. CSEE J. Power Energy Syst. 2020, 6, 489-495. [CrossRef]

51. Ghiani, E.; Galici, M.; Mureddu, M.; Pilo, F. Impact on Electricity Consumption and Market Pricing of Energy and Ancillary Services during Pandemic of COVID-19 in Italy. Energies 2020, 13, 3357. [CrossRef]

52. Ioannidis, J.P.; Jha, P. Does the COVID-19 Pandemic Provide an Opportunity to Eliminate the Tobacco Industry? Lancet Glob. Health 2021, 9, e12-e13. [CrossRef]

53. Babuna, P.; Yang, X.; Gyilbag, A.; Awudi, D.A.; Ngmenbelle, D.; Bian, D. The Impact of COVID-19 on the Insurance Industry. Int J. Environ. Res. Public Health. 2020, 17, 5766. [CrossRef]

54. Wang, Y.; Zhang, D.; Wang, X.; Fu, Q. How Does COVID-19 Affect China's Insurance Market? Emerg. Mark. Financ. Trade 2020, 56, 2350-2362. [CrossRef]

55. Gamil, Y.; Alhagar, A. The Impact of Pandemic Crisis on the Survival of Construction Industry: A Case of COVID-19. Mediterr. J. Soc. Sci. 2020, 11, 122. [CrossRef]

56. Alsharef, A.; Banerjee, S.; Uddin, S.M.; Albert, A.; Jaselskis, E. Early Impacts of the COVID-19 Pandemic on the United States Construction Industry. Int. J. Environ. Res. Public Health 2021, 18, 1559. [CrossRef]

57. Nicorescu, A.I.; Hălălișan, A.F.; Popa, B.; Neykov, N. Challenges for FSC forest certification: Audits in the context of pandemic COVID-19. Forests 2021, 12, 997. [CrossRef]

58. Stanturf, J.A.; Mansuy, N. COVID-19 and forests in Canada and the United States: Initial assessment and beyond. Front. For. Glob. Chang. 2021, 101, 101. [CrossRef]

59. Qiu, J.; Shen, B.; Zhao, M.; Wang, Z.; Xie, B.; Xu, Y. A Nationwide Survey of Psychological Distress Among Chinese People in the COVID-19 Epidemic: Implications and Policy Recommendations. Gen. Psychiatry 2020, 33, e100213. [CrossRef]

60. Xiang, Y.T.; Yang, Y.; Li, W.; Zhang, L.; Zhang, Q.; Cheung, T. Timely Mental Health Care for the 2019 Novel Coronavirus Outbreak is Urgently Needed. Lancet Psychiatry 2020, 7, 228-229. [CrossRef]

61. Zhang, J.; Wu, W.; Zhao, X.; Zhang, W. Recommended Psychological Crisis Intervention Response to the 2019 Novel Coronavirus Pneumonia Outbreak in China: A Model of West China Hospital. Precis. Clin. Med. 2020, 3, 3-8. [CrossRef]

62. Li, W.; Yang, Y.; Liu, Z.-H.; Zhao, Y.-J.; Zhang, Q.; Zhang, L. Progression of Mental Health Services during the COVID-19 Outbreak in China. Int. J. Biol. Sci. 2020, 16, 1732-1738. [CrossRef]

63. Chao, M.; Chen, X.; Liu, T.; Yang, H.; Hall, B.J. Psychological Distress and State Boredom during the COVID-19 Outbreak in China: The Role of Meaning in Life and Media Use. Eur. J. Psychotraumatol. 2020, 11, 1769379. [CrossRef]

64. Liu, R.; Pieniak, Z.; Verbeke, W. Food-Related Hazards in China: Consumers' Perceptions of Risk and Trust in Information Sources. Food Control. 2014, 46, 291-298. [CrossRef]

65. Yang, C.C.; Chen, J.X.; Yang, W.C. The Impact of the Amendment of Taiwan's Certified Public Accountant Act in 2007 on Large Accounting Firms. Sustainability 2020, 13, 1229. [CrossRef]

66. Chen, J.; Yang, C.C. Competitive Revenue Strategies in the Medical Consumables Industry: Evidence from Human Resources, Research and Development Expenses and Industry Life Cycle. Int J. Environ Res Public Health 2021, 18, 3180. [CrossRef] [PubMed]

67. Chen, J.; Yang, C.C. The impact of the National Nutrition Program 2017-2030 on people's food purchases: A revenue-based perspective. Nutrients 2021, 13, 3030. [CrossRef]

68. Banker, R.D.; Chang, H.; Cufnningham, R. The Public Accounting Industry Production Function. J. Account. Econ. 2003, 35, 255-281. [CrossRef]

69. Christensen, L.R.; Greene, W.H. Economies of scale in U.S. electric power generation. J. Polit. Econ. 1976, 84, 655-676. [CrossRef]

70. Chen, Q.; Schipper, K. Future directions for Chinese accounting research. China J. Account. Res. 2008, 1, 1-10. [CrossRef]

71. Du, M.; Boateng, A. State ownership, institutional effects and value creation in cross-border mergers \& acquisitions by Chinese firms. Int. Bus. Rev. 2015, 24, 430-442. [CrossRef]

72. Gulzar, M.A.; Cherian, J.; Hwang, J.; Jiang, Y.; Sial, M.S. The impact of board gender diversity and foreign institutional investors on the corporate social responsibility (CSR) engagement of Chinese listed companies. Sustainability 2019, 11, 307. [CrossRef]

73. Huang, J. Corporate social responsibility and financial performance: The moderating role of the turnover of local officials. Financ. Res. Lett. 2021, 102497. [CrossRef]

74. Hu, Y.; Ma, S.; Xu, X.; Wang, Y. CEO Identity Difference, Ownership Pattern and Long-Term Investment: Evidence from Chinese Family Listed Firms. In Proceedings of the Fifteenth International Conference on Management Science and Engineering Management, Toledo, Spain, 31 July 2021; pp. 440-451.

75. Zhang, C.; Jiang, J.; Jin, H.; Chen, T. The impact of COVID-19 on consumers' psychological behavior based on data mining for online user comments in the catering industry in China. Int. J. Environ. Res. Public Health 2021, 18, 4178. [CrossRef] 
76. Jin, X.; Li, J.; Song, W.; Zhao, T. The impact of COVID-19 and public health emergencies on consumer purchase of scarce products in China. Front. Public Health 2020, 8, 866. [CrossRef]

77. He, L.J.; Chen, J. Does Mandatory Audit Partner Rotation Influence Auditor Selection Strategies? Sustainability 2021, 13, 2058. [CrossRef]

78. Nie, D.; Panfilova, E.; Samusenkov, V.; Mikhaylov, A. E-Learning Financing Models in Russia for Sustainable Development. Sustainability 2020, 12, 4412. [CrossRef]

79. Yumashev, A.; Ślusarczyk, B.; Kondrashev, S.; Mikhaylov, A. Global Indicators of Sustainable Development: Evaluation of the Influence of the Human Development Index on Consumption and Quality of Energy. Energies 2020, 13, 2768. [CrossRef] 